\title{
Nursery Soil Amendments for Cashew Seedling Production: A Comparative Analysis of Coffee Husk and NPK
}

\author{
Beatrice A. Nduka ${ }^{1}$, Daniel B. Adewale ${ }^{2}$, Olorunfemi Sunday O. Akanbi ${ }^{1} \&$ Kayode B. Adejobi ${ }^{1}$ \\ ${ }^{1}$ Department of Agronomy, Cocoa Research Institute of Nigeria, Idi-Ayunre, Ibadan, Nigeria \\ ${ }^{2}$ Department of Biological Sciences, Ondo State University of Science and Technology, Okitipupa, Nigeria \\ Correspondence: Beatrice A. Nduka, Department of Agronomy, Cocoa Research Institute of Nigeria (CRIN), \\ P.M.B 5244, Idi-Ayunre, Ibadan, Oyo State, Nigeria. Tel: 234-802-9592-716. E-mail: \\ beatricenduka@yahoo.com
}

Received: November 16, 2014 Accepted: December 25, 2014 Online Published: February 15, 2015

doi:10.5539/jas.v7n3p111 URL: http://dx.doi.org/10.5539/jas.v7n3p111

\begin{abstract}
Amendment of nursery soil with nutrient-containing compounds could promote seedling development. The utility of coffee husk and the optimum quantity needed in sole or combination with NPK for enhanced cashew seedling development was investigated. Medium size cashew nuts were raised for 20 weeks in six nutritional treatments. There were three coffee husk application rates $\left(0.0021 \mathrm{~g}^{-1} \mathrm{Kg}, 0.0041 \mathrm{~g}^{-1} \mathrm{Kg}\right.$ and $\left.0.0062 \mathrm{~g}^{-1} \mathrm{Kg}\right), \mathrm{CH}$ and NPK (0.00208 $\mathrm{g}^{-1} \mathrm{Kg} \mathrm{CH}$ and $0.00016 \mathrm{~g}^{-1} \mathrm{Kg}$ NPK), $0.00016 \mathrm{~g}^{-1} \mathrm{Kg}_{\mathrm{NPK}}$ and a control in $3 \mathrm{Kg}$ of soil. Leaf count (LC), stem girth (SG), plant height (PH) and leaf area (LA) were measured five times. Amended nursery soil significantly $(\mathrm{P}<0.05)$ and positively affected the performance of cashew seedling. Potted nursery soil amended with higher $\left(\geq 0.0041 \mathrm{~g}^{-1} \mathrm{Kg}\right) \mathrm{CH}$ concentration and $\mathrm{CH} / \mathrm{NPK}$ significantly $(\mathrm{P}<0.05)$ increased LC, SG, $\mathrm{PH}$ and LA at every periodic intervals of measurement. The five sequential intervals of measuring LC, LA, SG and $\mathrm{PH}$ showed different trend patterns: linear, quadratic and cubic with respect to each treatment. Post-experiment soil and plant nutritional test revealed that the $\mathrm{N}, \mathrm{P}, \mathrm{K}, \mathrm{Ca}, \mathrm{Mg}$, soil $\mathrm{pH}$, soil organic carbon (SOC), and soil organic matter $(\mathrm{SOM})$ were significantly $(\mathrm{P}<0.05)$ higher compared to the control. $\mathrm{CH}$ with $0.00625 \mathrm{~g}^{-1} \mathrm{Kg}$ concentration increased soil $\mathrm{pH}$, SOC, SOM, N, K, C, Mg and leaf N by $10.20 \%, 10.50 \%$, $19.20 \%, 8.33 \%, 42.38 \%, 25.00 \%, 50.00 \%$ and $93.20 \%$ respectively. Post experiment evaluation revealed that the five nutritional treatments significantly aided higher biomass. However, addition of $18.75 \mathrm{~g}$ coffee husk to $3 \mathrm{Kg}$ of soil was most effective for improved cashew seedling growth and development.
\end{abstract}

Keywords: cashew, coffee husk, growth, NPK, nutrient uptake

\section{Introduction}

Cashew plant (Anacardium occidentale L.) is an important tree-nut crop; according to Mofa (2007) it ranks third in international trade after hard nuts (Cocos nucifera) and almonds (Prunus dulcis). Cashew, an evergreen perennial may be up to 15 metres high, the medium sized alternately arranged leaves may be oval in shape (Grieve, 2004). The dense foliage characteristic makes it suitable as wind break for erosion control and degraded land reclamation.

Flowering occurs at the end of wet season. Panicles are produced at the end of new shoots with majority at the periphery of the tree canopy. The kidney shaped nut is the true fruit attached to the bottom of the apple, the pseudo fruit. Both nut and apple are good for confectionery purposes. The apple is three to six times richer in vitamin C than oranges (Franco \& Janzantti, 2005; Soares et al., 2007; Sivagurunathan et al., 2010). The cashew nut is very rich in essential unsaturated fatty acids which are beneficial to both the heart and arteries. Akinhanmi and Atasie (2008) remarked that cashew nut consumption may prevent arteriosclerosis and hypertension.

Soil factor and the inherent nutrition determine crop productivity (Chintala et al., 2012a, 2012b). Documented reports (Rajesh et al., 2003; Veeken et al., 2005, Janvier et al., 2007, Lazcano et al., 2009; Yadessa et al., 2010) have indicated that amending agricultural soils with organic matter aided plant nutrition and enhanced physicochemical and biological characteristics of the soil on the field. The use of mineral and organic sources of nutrient in varied proportion evolved from long experiences in soil fertility management (Rajesh et al., 2003; Bationo \& Waswa, 2011). 
Information concerning the optimum quantity of nutritional constituents in nursery pot soil for cashew seedling is limited. In most cases, top soils are scraped for use as nursery soils to raise seedlings. The survival of seedling at transplanting is partly dependent on the nutritional condition of the medium in which they developed. Poor nutrition for seedlings at the juvenile stage may result in growth and developmental defects, poor establishment of seedling on the field, slow growth, reduced survival percentage etc.

Bulky organic residue from the processing of coffee contains degradable organic matter which can be utilized as composting product. Literature on the use of coffee waste as a soil amendment is limited; however, some experiments (Tenaw \& Kelsa, 1998; Zake et al., 2000; Preethu et al., 2007; Nguyen et al., 2013) indicated that coffee waste (coffee husk) is a valuable organic fertilizer, particularly for highly weathered soils of the humid tropics. Tuan (2005) reported that coffee husk compost supplemented with lime and phosphorus fertilizer resulted in long time of composting process, slow degradation of organic matter.

Coffee husk are available wastes in coffee plantation, however, its utility in the composting system for soil nutrient amendment is low. It is therefore worthwhile to investigate its nutritional potential especially on cashew seedlings. Therefore, the present study seeks to investigate the nutritional status of various proportions of sole coffee husk and coffee husk-NPK combinations with respect to the seedling developments of cashew.

\section{Materials and Methods}

The soil for the experiment was sandy loam, collected within the plantation premises of the Cocoa Research Institute of Nigeria (CRIN), Ibadan (Lat. $0.7^{\circ} 1^{\prime} \mathrm{N}$ and Long. $03^{\circ} 52^{\prime} \mathrm{E}$ ) at the depth of $0-15 \mathrm{~cm}$. The collected soil was mixed, air dried and sieved with a $2 \mathrm{~mm}$ mesh. Coffee seed coats (husk) were obtained after plot harvest and processing of coffee at CRIN, Ibadan. The husks were air dried under shade, crushed, blended into powder and screen thorough $1 \mathrm{~mm}$ sieve. Chemical analysis of the soil and the coffee husk $(\mathrm{CH})$ was done as described by Cater (1993). Soil $\mathrm{pH}$ was determined with a $\mathrm{pH}$ meter while soil organic matter was done by wet oxidation method (Waikley \& Black, 1943). Exchangeable K, Ca, Mg were extracted using ammonium acetate (Chintala et al., 2014a). The properties of the soil and the coffee husk are presented in Table 1. The polythene bags were filled with three kilogram soil.

Disease-free and viable Cashew nuts of medium size from the cashew germplasm plot at CRIN, Ibadan were planted at one nut per polythene bag. Following the recommendation of Zake et al. (2000), the treatments were incorporated into the soil by ring application at 4 weeks after planting. The experiment involved six nutritional treatments, the concentrations of each nutritional treatment was presented in Table 2. The experiment was laid out in completely randomized design with three replications. The plot size was ten seedlings per treatment. The seedlings were monitored for six month. Manual weeding was done as at when due.

Plant height, stem girth, leaf area and the number of leaves/plant were recorded at every four weeks until the 20th weeks after planting when the experiment was terminated. At termination of the experiment, fresh biomass was obtained before destructive sampling. The root weight and length (25 roots of uniform length) were measured per plant. The root and shoot were oven-dried differently and their weight determined using the Metler sensitive weighing balance. The nutrients uptake of the Cashew leaves and the post experiment soil nutrient composition were determined at harvest for each treatment and left over soil following the method described by Tel and Hagarty (1984).

The data were subjected to the statistical analysis using SAS, version 9.2, SAS (2007). Analysis of variance was done using the PROC GLM procedure in SAS. Means were separated with Turkey's Studentized Range (HSD) and Duncan New Multiple Range Test (DNMRT). The data taken at intervals were further subjected to trend analysis in R (R-Team, 2010) using the orthogonal polynomial coefficients in Gomez and Gomez (1984) to understand the behavioural pattern of each parameter with sequence and timing.

\section{Results}

The results of the physico-chemical properties of the soil and the chemical compositions of the coffee husk $(\mathrm{CH})$ before the experiment were presented in Table 1. The soil had higher proportion of the sand, clay, $\mathrm{Ca}$ and $\mathrm{Mg}$; this indicates that the textural class of the soil used was sandy loam. The soil and the $\mathrm{CH}$ were slightly acidic with equal $\mathrm{pH}$ of 5.3 (Table 1). 
Table 1. The properties of the soil and the coffee husk

\begin{tabular}{lll}
\hline Physical Properties & Soil & Coffee Husk \\
\hline Sand & $60.80 \mathrm{~g} \mathrm{~kg}^{-1}$ & - \\
$\mathrm{Silt}$ & $9.00 \mathrm{~g} \mathrm{~kg}^{-1}$ & - \\
Clay & $30.20 \mathrm{~g} \mathrm{~kg}^{-1}$ & - \\
Textural class & Sandy Loam & - \\
Chemical Properties & & \\
Soil $\mathrm{P}^{\mathrm{H}}\left(\mathrm{H}_{2} \mathrm{O}\right) 1: 1$ & 5.30 & 7.41 \\
Organic matter & $1.22 \%$ & - \\
Organic carbon & $3.03 \mathrm{~g} / \mathrm{kg}$ & - \\
Total Nitrogen & $0.06 \mathrm{~g}$ & $0.48 \%$ \\
Available Phosphorus & $1.03 \mathrm{mg} \mathrm{kg}$ & $19.10 \mathrm{mgKg}^{-1}$ \\
Exchangeable Bases & & \\
$\mathrm{K}^{+}$ & $0.27 \mathrm{cmol} / \mathrm{kg}^{-1}$ & $5.71 \mathrm{mgKg}^{-1}$ \\
$\mathrm{Ca}^{2+}$ & $4.10 \mathrm{cmol} / \mathrm{kg}^{-1}$ & $8.00 \mathrm{mgKg}^{-1}$ \\
$\mathrm{Mg}^{2+}$ & $2.00 \mathrm{cmol} / \mathrm{kg}^{-1}$ & $0.46 \mathrm{mgKg}^{-1}$ \\
$\mathrm{Na}^{+}$ & $0.92 \mathrm{cmol} / \mathrm{kg}^{-1}$ & $2.40 \mathrm{mgKg}^{-1}$ \\
\hline
\end{tabular}

Table 2 shows the treatments combinations and the various rates of the applied materials used for the experiment.

Table 2. Treatment combinations and concentrations of the treatments applied to the soil

\begin{tabular}{llll}
\hline $\mathrm{S} / \mathrm{N}$ & Treatments & Treatment codes & Application rates $\left(\mathrm{g}^{-1} \mathrm{Kg}\right)$ \\
\hline 1 & Control & $\mathrm{T} 1$ & - \\
2 & $6.25 \mathrm{~g} \mathrm{CH}$ & $\mathrm{T} 2$ & $0.00208 \mathrm{CH}$ \\
3 & $12.5 \mathrm{~g} \mathrm{CH}$ & $\mathrm{T} 3$ & $0.00416 \mathrm{CH}$ \\
4 & $18.75 \mathrm{~g} \mathrm{CH}$ & $\mathrm{T} 4$ & $0.00625 \mathrm{CH}$ \\
5 & $6.25 \mathrm{~g} \mathrm{CH}+0.5 \mathrm{~g} \mathrm{NPK}$ & $\mathrm{T} 5$ & $0.00208 \mathrm{CH}+0.00016 \mathrm{NPK}$ \\
6 & $0.5 \mathrm{~g} \mathrm{NPK}$ & $\mathrm{T} 6$ & $0.00016 \mathrm{NPK}$ \\
\hline
\end{tabular}

Note. $\mathrm{CH}$ - Coffee Husk.

Table 3 presented the ANOVA summary, the mean and the coefficient of variation of the four parameters measured at five periodic intervals. There existed significant $(\mathrm{P} \leq 0.05)$ variation among the six treatments for each interval of growth measurement with respect to the fifth leaf count and leaf area (Table 3). The first four initial periodic leave counts and the five periodic measured stem girth and plant height could not be distinguished by the six treatments (Table 3). The least coefficient of variation $(9.65 \%)$ occurred in LA5 while the highest $(95.26 \%)$ was observed in SG4. 
Table 3. Summary of analysis of variance for four growth parameters measured at two weeks intervals

\begin{tabular}{|c|c|c|c|c|c|c|}
\hline & \multirow[b]{2}{*}{ DF } & \multicolumn{5}{|c|}{ Mean Squares } \\
\hline & & $\mathrm{LC} 1$ & LC2 & LC3 & $\mathrm{LC} 4$ & LC5 \\
\hline Treatments & 5 & 7.61 & 26.38 & 16.81 & 24.62 & $39.98^{*}$ \\
\hline Error & 10 & 7.22 & 24.77 & 20.93 & 28.38 & 12.99 \\
\hline Mean & & 10.19 & 11.69 & 12.47 & 15.05 & 13.44 \\
\hline \multirow[t]{2}{*}{ CV $(\%)$} & & 26.36 & 42.56 & 36.68 & 35.38 & 26.81 \\
\hline & & SG1 & SG2 & SG3 & SG4 & SG5 \\
\hline Treatment & 5 & 0.01 & 0.03 & 0.01 & 0.21 & 0.02 \\
\hline Error & 10 & 0.01 & 0.04 & 0.01 & 0.33 & 0.02 \\
\hline Mean & & 0.35 & 0.64 & 0.54 & 0.60 & 0.77 \\
\hline \multirow[t]{2}{*}{ CV $(\%)$} & & 29.23 & 32.67 & 25.63 & 95.26 & 20.32 \\
\hline & & PH1 & $\mathrm{PH} 2$ & PH3 & PH4 & PH5 \\
\hline Treatment & 5 & 5.49 & 24.91 & 10.81 & 43.22 & 31.36 \\
\hline Error & 10 & 25.97 & 49.90 & 38.63 & 44.30 & 42.74 \\
\hline Mean & & 17.53 & 21.14 & 19.93 & 21.62 & 20.79 \\
\hline \multirow[t]{2}{*}{ CV (\%) } & & 29.07 & 33.40 & 31.17 & 30.77 & 31.44 \\
\hline & & LA1 & LA2 & LA3 & LA4 & LA5 \\
\hline Treatment & 5 & $133.31 * * *$ & $136.85 * * *$ & $111.12 * * *$ & $109.24 * * *$ & $129.64 * * *$ \\
\hline Error & 10 & 1.71 & 3.77 & 6.29 & 4.10 & 4.81 \\
\hline Mean & & 13.86 & 16.30 & 18.75 & 20.87 & 22.73 \\
\hline CV (\%) & & 9.43 & 11.91 & 13.38 & 9.71 & 9.65 \\
\hline
\end{tabular}

Note. LC - Leaf count; SG-Stem girth; PH - Plant height; LA - Leaf area; 1-5 epithet - Intervals of data recording; DF - Degree of freedom; CV (\%) - Coefficient of Variation; * ${ }^{* *}$ and ${ }^{* * *}$ - Significance at $\mathrm{P}=0.05,0.01$ and 0.001 .

From Table 4, the values of leaf count and stem girth for the five intervals differs significantly $(P \leq 0.05)$ in the first four treatments, T1 to T4. The five periodic measurements of the plant height of the cashew seedlings differed significantly $(\mathrm{P}<0.05)$ under treatments $\mathrm{T} 1, \mathrm{~T} 3, \mathrm{~T} 4$ and T5. However, each of the five periodic intervals of the leaf area assessed significantly $(\mathrm{P} \leq 0.001)$ differed under each of the six treatments. Leaf count and stem girth did not differ in treatments T5 and T6. Moreover, the sole NPK treatment could not differentiate among the five measured periodic plant heights of the cashew seedlings. The highest means were observed in treatments T2, T3, T3 and T6 for leaf count $(15.26)$, stem girth $(0.62 \mathrm{~cm})$, plant height $(22.02 \mathrm{~cm})$ and leaf area $(28.3)$ respectively (Table 4). 
Table 4. Variation and mean of the six treatments with respect to five intervals of data recording on leaf count, stem girth, plant height and leaf area

\begin{tabular}{|c|c|c|c|c|c|c|c|}
\hline & \multirow[b]{2}{*}{$\mathrm{DF}$} & \multicolumn{6}{|c|}{ Mean Squares } \\
\hline & & $\mathrm{T} 1$ & $\mathrm{~T} 2$ & $\mathrm{~T} 3$ & $\mathrm{~T} 4$ & T 5 & T 6 \\
\hline Leaf Count & 4 & $33.15^{*}$ & $35.35^{*}$ & $16.60^{*}$ & $10.16^{*}$ & 14.18 & 11.35 \\
\hline Error & 8 & 7.95 & 6.57 & 2.69 & 2.24 & 11.94 & 3.28 \\
\hline Mean & & 14.06 & 15.26 & 12.93 & 13.00 & 10.30 & 9.87 \\
\hline CV (\%) & & 20.04 & 16.79 & 12.69 & 11.51 & 33.56 & 18.34 \\
\hline Stem Girth & 4 & $0.11 * *$ & $0.11 * * *$ & $0.04 * * *$ & $0.09 * * *$ & 0.23 & 0.05 \\
\hline Error & 8 & 0.01 & 0.01 & 0.01 & 0.01 & 0.35 & 0.02 \\
\hline Mean & & 0.58 & 0.60 & 0.62 & 0.51 & 0.70 & 0.47 \\
\hline CV (\%) & & 16.51 & 8.46 & 12.40 & 17.35 & 84.39 & 35.23 \\
\hline Plant Height & 4 & $3.91 * * *$ & 15.14 & $14.77 *$ & $30.76^{*}$ & $37.16^{*}$ & 58.25 \\
\hline Error & 8 & 0.39 & 13.46 & 2.97 & 4.94 & 11.53 & 98.09 \\
\hline Mean & & 18.70 & 21.12 & 22.02 & 20.24 & 20.38 & 18.76 \\
\hline CV (\%) & & 3.34 & 17.37 & 7.82 & 10.98 & 16.66 & 52.78 \\
\hline Leaf Area & 4 & $49.03 * * *$ & $53.11 * * *$ & $31.69 * * *$ & $31.98 * * *$ & $23.88 * * *$ & $43.34 * * *$ \\
\hline Error & 8 & 0.45 & 1.62 & 1.27 & 1.94 & 0.49 & 2.08 \\
\hline Mean & & 10.24 & 14.60 & 16.45 & 23.06 & 18.35 & 28.30 \\
\hline CV (\%) & & 6.58 & 8.71 & 6.86 & 6.04 & 3.85 & 5.10 \\
\hline
\end{tabular}

Note. DF - Degree of freedom; CV (\%) - Coefficient of Variation; *, ** and *** - Significance at $\mathrm{P}=0.05,0.01$ and 0.001 .

Table 5 presents the response in trend of the juvenile growth parameters of cashew seedlings with respect to each of the six treatments. For the control (T1), the response of the five periodic measures of the leaf area (LA) from week four to 20 were significantly $(\mathrm{P}<0.01)$ linear and quadratic, while the response of stem girth $(\mathrm{SG})$ to the same treatment were significantly $(\mathrm{P} \leq 0.05)$ linear and cubic. The trend of response of LA and leaf count (LC) was significantly $(\mathrm{P} \leq 0.05)$ linear for the three treatments $(\mathrm{T} 2, \mathrm{~T} 3$ and $\mathrm{T} 4)$ which contain different levels of $\mathrm{CH}$ in sole (Table 5). The response of SG to the three treatments were significantly $(\mathrm{P} \leq 0.05)$ linear and cubic. Plant height $(\mathrm{PH})$ showed significant $(\mathrm{P}<0.05)$ linear trend response in $\mathrm{T} 4$ (the treatment with the highest content of $\mathrm{CH}$ in sole). Significant $(\mathrm{P}<0.01)$ linear and significant $(\mathrm{P}<0.05)$ cubic response was observed for $\mathrm{LA}$ and $\mathrm{PH}$ respectively in T5. In Table 5, only LA responded linearly at $\mathrm{P}=0.05$ level of significance when the treatment was solely NPK (T6). 
Table 5. Trend analysis of the five intervals of growth measurements on leaf area, leaf count, plant height and stem girth with respect to six treatments

\begin{tabular}{|c|c|c|c|c|c|}
\hline Sources of Variation & $\mathrm{Df}$ & MS_LA & MS_LC & MS_PH & MS_SG \\
\hline \multicolumn{6}{|l|}{$T 1$} \\
\hline Linear & 1 & $184.07 * * *$ & 1.63 & 1.323 & $0.14700^{*}$ \\
\hline Quadratic & 1 & $9.04 * *$ & 106.88 & 14.059 & 0.00381 \\
\hline Cubic & 1 & 2.80 & 6.08 & 0.091 & $0.28033 * *$ \\
\hline Quartic & 1 & 0.21 & 18.01 & 0.174 & 0.02835 \\
\hline Error & 10 & 0.69 & 25.33 & 11.968 & 0.02051 \\
\hline \multicolumn{6}{|l|}{$T 2$} \\
\hline Linear & 1 & $210.41 * * *$ & $124.03 * * *$ & 35.64 & $0.027170 * * *$ \\
\hline Quadratic & 1 & 1.80 & 0.21 & 16.72 & 0.00733 \\
\hline Cubic & 1 & 0.25 & 4.80 & 3.27 & $0.17101^{* *}$ \\
\hline Quartic & 1 & 0.00 & 12.39 & 3.45 & 0.00348 \\
\hline Error & 10 & 9.03 & 5.70 & 10.60 & 0.01215 \\
\hline \multicolumn{6}{|l|}{$T 3$} \\
\hline Linear & 1 & $125.83^{* * *}$ & $57.41 * *$ & 4.56 & $0.11781 * *$ \\
\hline Quadratic & 1 & 0.02 & 0.15 & 21.0 & 0.01449 \\
\hline Cubic & 1 & 0.65 & 8.01 & 7.15 & $0.06440 *$ \\
\hline Quartic & 1 & 0.27 & 0.87 & 27.83 & 0.00166 \\
\hline Error & 10 & 2.30 & 3.70 & 33.98 & 0.01029 \\
\hline \multicolumn{6}{|l|}{ T4 } \\
\hline Linear & 1 & $125.99 * * *$ & $38.53^{*}$ & $60.92 *$ & $0.26980 * * *$ \\
\hline Quadratic & 1 & 1.24 & 1.52 & 24.15 & 0.00707 \\
\hline Cubic & 1 & 0.64 & 0.13 & 23.41 & $0.09464 * *$ \\
\hline Quartic & 1 & 0.07 & 0.48 & 14.56 & 0.00031 \\
\hline Error & 10 & 5.59 & 4.83 & 10.61 & 0.00827 \\
\hline \multicolumn{6}{|l|}{$T 5$} \\
\hline Linear & 1 & $95.52 * *$ & 30.00 & 4.18 & 0.3513 \\
\hline Quadratic & 1 & 0.16 & 16.10 & 40.42 & 0.1778 \\
\hline Cubic & 1 & 0.29 & 10.21 & $70.23 *$ & 0.0460 \\
\hline Quartic & 1 & 0.02 & 0.43 & 33.84 & 0.3742 \\
\hline Error & 10 & 6.25 & 11.52 & 11.35 & 0.3658 \\
\hline \multicolumn{6}{|l|}{ T6 } \\
\hline Linear & 1 & $170.36^{*}$ & 10.80 & 105.84 & 0.08427 \\
\hline Quadratic & 1 & 2.21 & 22.88 & 49.40 & 0.00029 \\
\hline Cubic & 1 & 0.68 & 1.20 & 77.76 & 0.12610 \\
\hline Quartic & 1 & 0.14 & 10.52 & 0.00 & 0.00003 \\
\hline Error & 10 & 18.04 & 53.68 & 132.15 & 0.04448 \\
\hline
\end{tabular}

Note. *DF - Degree of freedom; MS_LA - Mean square leaf area; MS_LC - Mean square leaf count; MS_PHMean square Plant height; MS_SG- Mean square stem girth. 
Fresh and dry root related parameters in Table 6 were significantly enhanced by T4, T5 and T6. T6 significantly enhanced the outstanding performance of the cashew seedling for fresh and dry biomass (Table 6). In a follow up pattern behind T6, biomass yield (fresh or dry) was also enhanced in the sequence of T5 $>$ T4 $>$ T3 $>$ T2. For the five post-experiment variables assessed (Table 6), the lowest significant performance was observed in $\mathrm{T} 1$ (the control). Each of the five treatments significantly compensated for the root and shoot performances of cashew seedling.

Table 6. Post-experiment means of some agronomic parameters on the cashew seedlings raised on the six nutritional treatments

\begin{tabular}{llllll}
\hline Treatments & RL $(\mathrm{cm})$ & RFW $(\mathrm{g})$ & RDW $(\mathrm{g})$ & WPFW $(\mathrm{g})$ & WPDW $(\mathrm{g})$ \\
\hline T1 & $15.77 \mathrm{~d}$ & $3.27 \mathrm{~d}$ & $1.05 \mathrm{~d}$ & $18.17 \mathrm{e}$ & $9.12 \mathrm{e}$ \\
T2 & $20.70 \mathrm{c}$ & $5.50 \mathrm{c}$ & $2.58 \mathrm{c}$ & $34.42 \mathrm{~d}$ & $16.41 \mathrm{~d}$ \\
T3 & $24.80 \mathrm{c}$ & $7.50 \mathrm{~b}$ & $3.12 \mathrm{bc}$ & $35.53 \mathrm{c}$ & $17.12 \mathrm{~cd}$ \\
T4 & $31.72 \mathrm{~b}$ & $8.52 \mathrm{ab}$ & $3.76 \mathrm{ab}$ & $36.36 \mathrm{bc}$ & $18.06 \mathrm{c}$ \\
T5 & $39.01 \mathrm{a}$ & $9.36 \mathrm{a}$ & $4.26 \mathrm{a}$ & $37.30 \mathrm{~b}$ & $19.36 \mathrm{~b}$ \\
T6 & $35.67 \mathrm{ab}$ & $8.78 \mathrm{ab}$ & $3.85 \mathrm{ab}$ & $40.33 \mathrm{a}$ & $20.52 \mathrm{a}$ \\
Mean & 27.94 & 7.15 & 3.10 & 33.68 & 16.76 \\
CV\% & 5.85 & 6.69 & 9.66 & 1.09 & 2.22 \\
\hline
\end{tabular}

Note. RL - Root length; RFW - Root fresh weight; RDW - Root dry weight; WPFW - Whole plant fresh weight; WPDW - Whole plant dry weight. Means with the same alphabet are not significantly different.

Table 7 revealed the amount of various nutrient present in the leaves of cashew seedlings after being grown under different nutritional treatments. Among the six treatments, T4 had the highest N, P, K, Mg, Ca and Na; T6 followed in magnitude with respect to the mean values of $\mathrm{P}, \mathrm{K}$ and $\mathrm{Na}$ (Table 7). The least mean for each nutrient was however obtained in T1 (control). The coefficient of variation for the six treatments ranged between $0.61 \%$ (P) and $18.27 \%(\mathrm{Ca})$.

Table 7. Mean nutrient uptake of cashew seedlings under different nutritional treatments

\begin{tabular}{lllllll}
\hline Treatments & $\mathrm{N}(\%)$ & $\mathrm{P}(\mathrm{mg} / \mathrm{Kg})$ & $\mathrm{K}(\mathrm{mg} / \mathrm{Kg})$ & $\mathrm{Mg}(\mathrm{mg} / \mathrm{Kg})$ & $\mathrm{Ca}(\mathrm{mg} / \mathrm{Kg})$ & $\mathrm{Na}(\mathrm{mg} / \mathrm{Kg})$ \\
\hline T1 & $0.23 \mathrm{~d}$ & $14.22 \mathrm{f}$ & $2.49 \mathrm{f}$ & $0.50 \mathrm{~b}$ & $4.95 \mathrm{bc}$ & $0.42 \mathrm{e}$ \\
T2 & $0.42 \mathrm{~b}$ & $16.43 \mathrm{e}$ & $4.62 \mathrm{~d}$ & $0.57 \mathrm{~b}$ & $8.27 \mathrm{bc}$ & $0.44 \mathrm{e}$ \\
T3 & $0.46 \mathrm{~b}$ & $18.52 \mathrm{~d}$ & $4.87 \mathrm{c}$ & $0.60 \mathrm{~b}$ & $10.14 \mathrm{ab}$ & $0.62 \mathrm{~d}$ \\
T4 & $0.76 \mathrm{a}$ & $31.44 \mathrm{a}$ & $10.45 \mathrm{a}$ & $1.17 \mathrm{a}$ & $11.75 \mathrm{a}$ & $0.94 \mathrm{a}$ \\
T5 & $0.43 \mathrm{~b}$ & $21.13 \mathrm{c}$ & $4.41 \mathrm{e}$ & $1.03 \mathrm{a}$ & $10.74 \mathrm{ab}$ & $0.72 \mathrm{c}$ \\
T6 & $0.32 \mathrm{c}$ & $22.84 \mathrm{~b}$ & $7.25 \mathrm{~b}$ & $0.60 \mathrm{~b}$ & $5.40 \mathrm{c}$ & $0.83 \mathrm{~b}$ \\
Mean & 1.453 & 20.763 & 5.682 & 2.336 & 9.041 & 0.862 \\
CV(\%) & 1.71 & 0.16 & 1.85 & 1.59 & 18.27 & 2.91 \\
\hline
\end{tabular}

Note. Means with the same alphabet are not significantly different.

The chemical properties in the residual soil after the experiment were presented in Table 8. Except for Nitrogen (which had the highest (36.5\%) coefficient of variation), significant variation existed among the six treatments for all the chemical properties studied (Table 8). T3, T4 and T5 had significantly higher $\mathrm{pH}$, the least $\mathrm{pH}(4.43)$ was observed in the control (T1). T4 significantly $(\mathrm{P} \geq 0.05)$ had the lead means for OC, OM, K and Mg. However, T6 significantly ( $\mathrm{P} \geq 0.05$ ) had the lead means for $\mathrm{P}$ and $\mathrm{Na}$ in the experiment (Table 8). All the treatments except T1 had equal mean for Calcium. In the study, the control (T1) had the least mean for all the measured chemical properties (Table 8). 
Table 8. Post-experiment chemical composition of the residual soil media

\begin{tabular}{llllllllll}
\hline Treatments & $\mathrm{P}^{\mathrm{H}}$ & $\mathrm{OC}$ & $\mathrm{OM}$ & $\mathrm{N}$ & $\mathrm{P}$ & $\mathrm{K}$ & $\mathrm{Na}$ & $\mathrm{Ca}$ & $\mathrm{Mg}$ \\
\hline $\mathrm{T} 1$ & $4.43 \mathrm{~d}$ & $1.03 \mathrm{e}$ & $1.76 \mathrm{e}$ & $0.08 \mathrm{a}$ & $4.07 \mathrm{f}$ & $0.12 \mathrm{f}$ & $0.11 \mathrm{c}$ & $1.53 \mathrm{~b}$ & $1.44 \mathrm{~d}$ \\
$\mathrm{~T} 2$ & $4.95 \mathrm{~b}$ & $1.77 \mathrm{~b}$ & $3.02 \mathrm{bc}$ & $0.11 \mathrm{a}$ & $4.56 \mathrm{e}$ & $0.26 \mathrm{c}$ & $0.11 \mathrm{c}$ & $2.04 \mathrm{a}$ & $2.34 \mathrm{c}$ \\
$\mathrm{T} 3$ & $5.20 \mathrm{a}$ & $1.79 \mathrm{~b}$ & $3.13 \mathrm{~b}$ & $0.12 \mathrm{a}$ & $4.81 \mathrm{~d}$ & $0.31 \mathrm{~b}$ & $0.12 \mathrm{c}$ & $2.04 \mathrm{a}$ & $2.35 \mathrm{c}$ \\
$\mathrm{T} 4$ & $5.10 \mathrm{ab}$ & $2.32 \mathrm{a}$ & $4.03 \mathrm{a}$ & $0.14 \mathrm{a}$ & $4.90 \mathrm{c}$ & $0.46 \mathrm{a}$ & $0.15 \mathrm{~b}$ & $2.27 \mathrm{a}$ & $2.84 \mathrm{a}$ \\
T5 & $5.17 \mathrm{a}$ & $1.62 \mathrm{c}$ & $2.75 \mathrm{c}$ & $0.12 \mathrm{a}$ & $5.32 \mathrm{~b}$ & $0.23 \mathrm{~d}$ & $0.12 \mathrm{c}$ & $2.13 \mathrm{a}$ & $2.33 \mathrm{c}$ \\
T6 & $4.60 \mathrm{c}$ & $1.31 \mathrm{~d}$ & $2.26 \mathrm{~d}$ & $0.11 \mathrm{a}$ & $12.20 \mathrm{a}$ & $0.15 \mathrm{e}$ & $0.21 \mathrm{a}$ & $2.13 \mathrm{a}$ & $2.74 \mathrm{~b}$ \\
Mean & 4.907 & 1.640 & 2.827 & 0.108 & 5.977 & 0.256 & 0.138 & 2.025 & 2.39 \\
$\mathrm{CV}(\%)$ & 1.74 & 1.1 .67 & 3.47 & 36.50 & 0.161 & 5.14 & 11.73 & 6.70 & 1.57
\end{tabular}

Note. OC- Organic carbon; OM - Organic matter. Means with the same alphabet are not significantly different.

\section{Discussion}

Düring and Gäth (2002) and Lal (2008) had remarked that the production of urban and industrial organic wastes is increasing worldwide; agricultural wastes are equally on the increase in most farms; sometimes to the level of becoming a menace in plantations and fields (Chintala et al., 2013, 2014b). Agbeniyi et al. (2011) had reported on the encumbering status of heaps of cocoa pod husk in cocoa plantation in Nigeria. Coffee husk heap of waste litters most coffee plantations after coffee processing. Agricultural wastes such as cocoa pod and coffee husk are of great efficient importance as degradable organic matter for composting. Development of strategies for organic waste disposal that prevent soil degradation and water contamination is necessary. However, Khaled et al. (2012) had reported on the productivity and biosafety of organic manure that it releases nutrients gradually and allows greater production with minor environment impact.

Moyin Jesu (2007) remarked that cocoa pod husk increased soil OM, N, P, K, Ca, Mg and pH. The major mineral elements present in the coffee husk were N, P, K, Mg, C and Na. Obatolu and Agboola (1991) had reported that cocoa pod husk $(\mathrm{CPH})$ manure contains high $\mathrm{Ca}, \mathrm{P}, \mathrm{K}$ and sizeable amount of useful organic constituents. The use of coffee husk as an organic amendment has been reported and reccommended by Veeken et al. (2005), Janvier et al. (2007), Lazcano et al. (2009) and Yadessa et al. (2010). According to them, amending agricultural soils with coffee husk as compost supplies plant nutrients and helps to improve the physicochemical and biological properties of the soil.

Miller and Miller (2000) admitted that the effect of organic material application to crop soil may not be apparent, but while its presence positively affects the immediate soil properties, nutrients are released gradually into the soil. The slow release of inherent nutrients in organic fertilizers had been identified to be responsible for the increase in crop yields from such plots in the subsequent years. The remark of Baldock and Nelson (2000) may explain for the reason for the slow nutrient release. According to them, the macronutrients, N, P and S present in the organic chemical structures are usually converted into inorganic forms before subsequent release into the soil as mineral nutrient.

The Nitrogen content in the soil was $0.06 \%$; this is lower than $0.09 \%$ being the critical level (Thong \& $\mathrm{Ng}, 1978$; Egbe et al., 1989; Aikpokpodion et al., 2010) required for cocoa cultivation. It is noteworthy that optimum $\mathrm{N}$ for most crops according to Sobulo and Osiname (1981) is $0.15 \%$. The exchangeable $\mathrm{K}(0.3 \mathrm{Cmol} / \mathrm{kg})$ in this study was equivalent to the critical level identified by Folorunso et al. (2000) to be adequate for crop growth.

The combination of organic and inorganic fertilizer aid the released of nutrient from organic sources and also reduce the quantity of the organic manure necessary for application into the soil. The effectiveness of using the combination of coffee husk and NPK as one of the treatments in this experiment was reflected on leaf mineral composition and growth parameters. This is in line with the report of Ofori et al. (2003) on the combination of cocoa pod husk and NPK. Their report further reiterated that, smaller cocoa pod husk is needed in ratio with NPK for a suitable potting medium to nurse cocoa seedling.

Santos et al. (2008) found that applying untreated coffee husk or coffee peel gave imbalance of nutrients in the coffee seedling leaves. The higher phosphorus recorded in this study $(0.00625)$ in the cashew leaves (T4:31.44) after termination of the experiment was in line with the study of Ogunlade and Aikpokpodion (2006). According to them, phosphorous concentration in leaf sample at specific growth stage is related to the performance of the 
crop. However, availability of $\mathrm{P}$ is enhanced in an acid soil following the application of organic amendments (Iyamuremye \& Dick, 1996; Materechera \& Mkhabela, 2002). The post experiment higher residual quantity of $\mathrm{P}$ seems to inform that the coffee husk has adequate nutrient composition. $\mathrm{P}$ availability as reported by Iyamuremye and Dick (1996) and Materechera and Mkhabela (2002) have been enhanced following the application of organic amendments to acidic soils. Coffee husk may also be a very important liming material for soil acidity amelioration.

The non-significant difference between sole NPK and NPK plus coffee husk on leaf count and stem girth of coffee in this study seem to suggest that the addition of coffee husk to NPK did not produce any compensatory influence on the number of leaves and stem girth of cashew seedling. However, the application of coffee husk at different sole rates resulted in positive and significant increase in leaf count, stem girth, plant height and leaf area. This is corroborated by some previous results (Rajesh et al., 2003; Veeken et al., 2005; Janvier et al., 2007; Lazcano et al., 2009; Yadessa et al., 2010); amendment of agricultural soils with organic matter as compost resulted in the improvement of the physico-chemical properties of the soil, nutrient release and morphological development of the hosted plants.

Most of the parameters exhibited significantly linear response. Hammed et al. (2011) and Adewale et al. (2013) obtained a corresponding result for growth parameters of established cashew seedlings on the field. The linearity feature of the increase in the number of leaves, girth circumference, plant height and leaf area in response to increasing time could be attributed to active cell division and elongation which accompany growth and development at juvenile stage (Adewale et al., 2013).

The result of the residual chemical composition of the medium after the termination of the experiment shows an increased in N, P and Na; Moyin Jesu (2008) and Ojeniyi et al. (2007) had made similar observation. Adejobi et al. (2011a, 2011b) found the residual effect of organo-mineral fertilizer and cocoa pod husk on the soil and leaf chemical composition like ours identified increase in $\mathrm{N}, \mathrm{P}, \mathrm{K}, \mathrm{Ca}, \mathrm{Mg}$ and $\mathrm{pH}$. Magnesium and Calcium are additional nutrient to N, P and $\mathrm{K}$ in coffee husk. However, the better performance of treatments with coffee husk over NPK could be due to the additional presence of Mg and Ca in coffee husk. The richness of N, P, K, Ca and $\mathrm{Mg}$ and high $\mathrm{pH}$ in organic materials observed in the present result is consistent with the previous studies (Owolabi et al., 2003; Rajesh et al., 2003).

The present work therefore seems to confirm that organic materials such as coffee husk do release N, P, K, Ca and $\mathrm{Mg}$ into soil when used alone or in combination with NPK. Application of fertilizers as amendments improved the chemical characteristics of the soil. This is in reference to the Integrated Soil Fertility Management (ISFM) principle (Vanlauwe, 2004). The reduction in mineral fertilizer application through their supplementation with organic sources, such as coffee husk makes the use of soil nutrient amendments affordable to small holder farmers, guarantees and improves soil life.

\section{Conclusion}

This study clearly showed that coffee husk improved physico-chemical properties of soil, improved the nutrient in the nursery soil medium and actively supported the morphological development of the cashew seedling. Since good morphological development of seedling enhances their better field establishment, the use of coffee husk to amend nursery soil is recommended. The appropriation of this organic material in agricultural system of nursery seedling production will profitably claim the waste (i.e. coffee husk) and ultimately supply nutrient to growing seedlings without adverse impact on soil biomes

\section{References}

Adejobi, K. B., Famaye, A. O., Adeniyi, D. O., Orisajo, S. B., \& Adeyemi, E. A. (2011a). Effect of cocoa pod husk and goat dung on nutrient content and growth performance of cashew (Anacardium occidentale). Adv. Environ. Biol., 5(7), 1536-1542.

Adejobi, K. B., Famaye, A. O., Adeniyi, D. O., Akanbi, O. S., \& Orisajo, S. B. (2011b). Comparative effect of organo-mineral fertilizer and cocoa pod husk ash on the soil, leaf chemical composition and growth performance of cacao (Theobroma cacao L.) in South-western Nigeria. Obeche J., 29(1), 212-217.

Adewale, B. D., Ibiremo, O. S., Odoh, N. C., \& Adeyemi, E. A. (2013). Genetic estimates and trend analysis of some growth parameters of cashew (Anacardium Occidentale L.), as influenced by nine nutrient combinations. Journal of Agricultural Biotechnology and Sustainable Development, 5(1), 6-11. http://dx.doi.org/10.5897/JABSD12.035

Agbeniyi, S. O., Oluyole, K. A., \& Ogunlade, M. O. (2011). Impact of cocoa pod husk fertilizer on cocoa production in Nigeria. World J. Agric. Sci., 7, 113-116. 
Aikpokpodion, P. E., Uloko, B., \& Edibo, G. (2010). Nutrient dynamics in soil and cashew (Anacardium occidentale L.) leaf and kernel in Kogi State, Nigeria. J. Appl. Biosci., 25, 1573-1578.

Akinhanmi, T. F., \& Atasie, V. N. (2008). Chemical composition and physicochemical properties of cashew nut (Anacardium occidentale) oil and cashew nut shell liquid. J. Agric. Food Environ. Sci., 2(1), 1-10.

Baldock, J. A., \& Nelson, P. N. (2000). Soil organic matter. In M. E. Sumner (Ed.), Handbook of soil science. CRC Press, Boca Raton, Florida.

Bationo, A., \& Waswa, B. S. (2011). New challenges and opportunities for integrated soil fertility management in Africa. In A. W. Bationo (Ed.), Innovation as key to the green revolution in Africa. Exploring the scientific facts (Vol. 1, pp. 3-18). http://dx.doi.org/10.1007/978-90-481-2543-2

Carter, M. R. (1993). Soil sampling and method of analysis (p. 823). Canadian society of soil science, Lewis publishers Boca Raton, United states of America.

Chintala, R., McDonald, L. M., \& Bryan, W. B. (2012a). Effect of soil water and nutrients on productivity of Kentucky bluegrass systems in acidic soils. Journal of Plant Nutrition, 35, 288-303. http://dx.doi.org/10.1080/01904167.2012.636131

Chintala, R., McDonald, L. M., \& Bryan, W. B. (2012b). Optimization of water potential and nutrient levels for Kentucky bluegrass-white clover mixture on acidic soils. Biotechnology, Agronomy, Society and Environment, 16, 167-177.

Chintala, R., Wimberly, M., Djira, G., \& Tulbure, M. (2013). Interannual variability of crop residue potential in the North Central region of the United States. Biomass and Bioenergy, 49, 231-238. http://dx.doi.org/10.1016/j.biombioe.2012.12.018

Chintala, R., Mollinedo, J., Schumacher, T. E., Malo, D. D., \& Julson, J. L. (2014a). Effect of biochars on chemical properties of acidic soil. Archives of Agronomy and Soil Science, 60(3), 393-404. http://dx.doi.org/10.1080/03650340.2013.789870

Chintala, R., Djira, G., Devkota, M., Prasad, R., \& Kumar, S. (2014b). Modeling the effect of temperature and precipitation on crop residue potential for the North Central Region of the United States. Agricultural Research, 3(2), 393-404.

Düring, R. A., \& Gäth, S. (2002). Utilization of municipal organic wastes in agriculture: Where do we stand, where will we go? J. Plant Nutr. Soil Sc., 165, 544-556. http://dx.doi.org/10.1002/1522-2624(200208)165:4\%3C544::AID-JPLN544\%3E3.0.CO;2-\#

Egbe, N. E., Ayodele, E. A., \& Obatolu, C. R. (1989). Soils and nutrition of cacao, coffee, kola, cashew and tea (pp. 3-28). Progress in Tree Crop Research, CRIN Ibadan.

Folorunso, O. O., Agboola, A. A., \& Adeoye, G. O. (2000). Evaluation of three fertilizer models for P and K recommendation in maize (Zea Mays). Jour. of Technical Educ., 2, 237-253.

Franco, M. R. B., \& Janzantti, N. S. (2005). Aroma of minor tropical fruits. Flavour Fragr. J., 20, 358-371. $\mathrm{http}: / / \mathrm{dx}$.doi.org/10.1002/ffj. 1515

Gomez, K. A., \& Gomez, A. A. (1984). Statistical procedures for agricultural Research (p. 680). New York: John Wiley \& Sons.

Grieve, M. (2004). "Cashew nut." A modern herbal. Retrieved December 24, 2014, from http://botanical.com/botanical/mgmh/c/casnut 29.html\#des

Hammed, L. A., Lawal, B. A., \& Kolapo, K. A. (2011). Growth and nutrient uptake of cashew (Anacardium occidentale L.) seedlings as affected by nut-size in the nursery. African Journal of Agricultural Research, 6(17), 3962-3971.

Iyamuremye, F., \& Dick, R. P. (1996). Organic amendments and phosphorus sorption by soils. Advances in Agronomy, 56, 139-185. http://dx.doi.org/10.1016/S0065-2113(08)60181-9

Janvier, C. F., Villeneuve, C., Alabouvette, V., Hermann, E., Matelle, T., \& Steinberg, C. (2007). Soil health though soil disease suppression: Which strategy from descriptors to indicators? Soil Biol.Biochem, 39, 1-23. http://dx.doi.org/10.1016/j.soilbio.2006.07.001

Khaled, A., Shaban, M., Abd El-Kader, G., \& Zeinab, K. M. (2012). Effect of soil amendments on soil fertility and sesame crop production under newly reclaimed soil conditions. Journal of Applied Sci. Research, 8, $1568-1575$. 
Lal, R. (2008). Soils and sustainable agriculture: A review. Agron. Sustain. Dev., 28, 57-64. http://dx.doi.org/10.1051/agro:2007025

Lazcano, C., Arnold, J., Tato, A., Zaller, J. G., \& Dominguez, J. (2009). Compost and verm-compost as nursery pot components: Effect of tomato plant growth and morphology. Spanish J. Agric. Res., 7, 944-951. http://dx.doi.org/10.5424/sjar/2009074-1107

Materechera, S. A., \& Mkhabela, T. S. (2002). The effectiveness of lime, chicken manure and leaf litter ash in ameliorating acidity in a soil previously under black wattle (Acacia mearnsili) plantation. Bioresource Technology, 85, 9-16. http://dx.doi.org/10.1016/S0960-8524(02)00065-2

Miller, D. M., \& Miller, W. P. (2000). Land application of wastes. In M. E. Sumner (Ed.), Handbook of soil science (p. 37). CRC Books.

Ministry of Food \& Agriculture (MOFA). (2007). Status of Ghana cashew industry. Retrieved from http://www.ghanacashewproducts.com12/24/2012:2.34pm

Moyin Jesu, E. I. (2007). Effect of Some Organic Fertilizers on Soil, Coffee Leaf Chemical Composition and Growth. University of Khatoum Journal of Agricultural Science, 15, 52-70.

Moyin Jesu, E. I. (2008). Comparative evaluation of different organic fertilizers on the soil fertilities leaf minerial composition and growth of dikanut (Irvingia gabonensis). Emirate, Journal of Food and Agricultural Science, 32(1), 17-23.

Nguyen, A. D., Tran, T. D., \& Vo Thi, P. K. (2013). Evaluation of coffee husk compost for improving soil fertility and sustainable coffee production in rural central highland of Vietnam. Resources and Environment, 3(4), 77-82.

Obatolu, C. R., \& Agboola, A. A. (1991). The potential of siam weed (Chromolaena odorata) as a source of organic matter for soils in the humid tropics. Proc. International symposium by the Laboratory of soil fertility and soil Biology. Katholieke University et Leuven (K.U.) and International Institute of Tropical Agriculture (IITA) held in Leuken. Belgium.

Ofori-Frimpong, K., Afrifa, A. A., Osei-Bonsu, K., \& Appiah, M. R. (2003). Cocoa/Coconut intercropping trial in Ghana: Effect of the cropping systems on soil nutrient dynamics (pp. 13-18). Paper presented at the 14th International Cocoa Research Conference, Accra Ghana.

Ogunlade, M. O., \& Aikpokpodion, P. O. (2006). Available Phosphorus and Some Micro-Nutrient Development, Contents of Cocoa Soils in Three Cocoa Growing Ecological Zones of Nigeria. Proceedings of 15th International Cocoa Research Conference 2006 (pp. 675-678). Costa Rica.

Ojeniyi, S. O., Owolabi, O., Akinola, O. M., \& Odedina, S. A. (2007). Field Study of effect of organomineral fertilizer on maize growth yield, soil and plant nutrient composition in Iiesa, Southwest Nigeria. Nigeria Journal of Soil Science, 19, 11-16.

Owolabi, O., Adeleye, A., Oladejo, B. T., \& Ojeniyi, S. O. (2003). Effect of wood ash on soil fertility and crop yield in South West Nigeria. Nigerian Journal of Soil Science, 13, 15-60.

Preethu, D. C., Prakash, B. N. U. H., Srinivasamurthy, C. A., \& Vasanthi, B. G. (2007). Maturity indices as an index to evaluate the quality of compost of coffee waste blended with other organic wastes. Proceedings of the International Confer-ence on Sustainable Solid Waste Management, September 5-7 (pp. 270-275). Chennai, India.

R Development Core Team. (2010). R: A language and environment for statistical computing. R Foundation for Statistical Computing, Vienna. Retrieved from http://www.R-project.org

Rajesh, C., Reddy, K. S., Naidu, M. V. S., \& Ramavataram, N. (2003). Production and evaluation of compost and vermicompost from solid organic wastes. Asian Journal of Microbiology, Biotechnology, and Environmental Science, 5, 307-311.

SAS Institute Inc. (2007). SAS OnlineDoc ${ }^{\circledR}$ 9.2. SAS Institute Inc., Cary, NC.

Santos, F. D. S., Souza, P. E. D., Pozza, E. A., Iranda, J. C., Carvalho, E. A., Fernandes, L. H. M., \& Pozza, E. A. A. A. (2008). Organic fertilization, nutrition and the progress of brown eye spot and rust in coffee tree. Pesq. Agropec. Bras., 43(7), 783-791. http://dx.doi.org/10.1590/S0100-204X2008000700001

Sivagurunathan, P., Sivasankari, S., \& Muthukkaruppan, S. M. (2010). Characterisation of Cashew Apple (Anacardium occidentale L.) Fruits Collected from Ariyalur District. J. Bio. Sci. Res., 2, 101-107. 
Soares, F. D., Pereira, T., Marques, M. O. M., \& Monteiro, A. R. (2007). Volatile and non-volatile chemical composition of the white guava fruit (Psidium guajava L.) at different stages of maturity. Food Chem., 100, 15-21. http://dx.doi.org/10.1016/j.foodchem.2005.07.061

Sobulo, R. A., \& Osiname, O. A. (1981). Soils and fertilizer use in Western Nigeria. Tech Bull., 11, $20-26$.

Tel, D. A., \& Hagarty, M. (1984). Soil and Plant analysis (p. 277). International Institute of Tropical Agriculture (IITA), Ibadan/University of Guelph, Ontario, Canada.

Tenaw, W., \& Kelsa, K. (1998). Residual effect of coffee husk/pulp on grain yield of maize. Proceedings of the $6^{\text {th }}$ Eastern and Southern Africa Regional Maize Conference, $21^{\text {st }}-25^{\text {th }}$ September 1998. Addis Ababa.

Thong, K. C., \& Ng, W. L. (1978). Growth and nutrient composition of monocrop cocoa plants in inland Malaysian soils. Proceedings of Int. Conf. Cocoa and Coconuts (pp. 186-286). Kuala Lumpar.

Tuan, B. (2005). Efficience of using coffee husk to applied for robusta coffee in central highland. Journal Soil Science, 22, 10-15.

Vanlauwe, B. (2004). Integrated soil fertility management research at TSBF: The framework, the principles, and their application. In A. Bationo (Ed.), Managing nutrient Cycles to Sustain Soil Fertility in Sub-Saharan Africa (pp. 25-42). Academy Science Publishers, AAS, Nairobi, Kenya.

Veeken, A. H. M., Blok, W. J., Curci, F., Coene, G. C. M., Termorshuizen, A. J., \& Hamelers, H. V. M. (2005). Improving quality of compost biowaste to enhance disease suppressiveness of compost-amended, peat-based potting mixes. Soil Biol. Biochem, 37, 2131-2140. http://dx.doi.org/10.1016/j.soilbio.2005.03.018

Walkey, A., \& Black, I. A. (1934). An Examination of dergtajaroff method for determining soil organic acid filtration method. Soil Sci., 37, 29-38. http://dx.doi.org/10.1097/00010694-193401000-00003

Yadessa, G. B., Bruggen, van A. H. C., \& Ocho, F. L. (2010). Effect of different soil amendments on bacterial wilt caused by ralstonia solancearum and on the yield of tomato. J Plant Pathol, 92, 429-440.

Zake, Y. K., Bwamiki, D. P., \& Nkwine, C. (2000). Soil management requirements for banana production on the heavy soils around Lake Victoria in Uganda. In K. Craenen, R. Ortiz, E. B. Karamura \& D. Vuylsteke (Eds.), Proceedings, First International Symposium on Banana and Plantain for Africa (pp. 285-292). Acta Horiticulturae.

\section{Copyrights}

Copyright for this article is retained by the author(s), with first publication rights granted to the journal.

This is an open-access article distributed under the terms and conditions of the Creative Commons Attribution license (http://creativecommons.org/licenses/by/3.0/). 